\title{
Hepatitis C Virus Genotype Distribution in Kermanshah Province, Western Iran
}

\author{
Reza Hatami Moghaddam ${ }^{1}$, Reza Alibakhshi ${ }^{2} \&$ Babak Sayyad $^{3}$ \\ ${ }^{1}$ Central Medical Laboratory of Kermanshah, Kermanshah University of Medical Sciences, Kermanshah, Iran \\ ${ }^{2}$ Department of Biochemistry, School of Medicine, Kermanshah University of Medical Sciences, Kermanshah, \\ Iran \\ ${ }^{3}$ Department of Infectious diseases, Kermanshah University of Medical Sciences, Kermanshah, Iran \\ Correspondence: Reza Hatami Moghaddam, Central Medical Laboratory of Kermanshah, Kermanshah \\ University of Medical Sciences, Kermanshah, Iran. Tel: 9883-3832-4060. E-mail: hatami.iau@gmail.com
}

Received: October 31, 2015

Accepted: November 27, $2015 \quad$ Online Published: January 7, 2016

doi:10.5539/mas.v10n2p138

URL: http://dx.doi.org/10.5539/mas.v10n2p138

\begin{abstract}
Six major hepatitis $\mathrm{C}$ virus genotypes have been characterized, which vary in their geographical distribution. Knowledge of the distribution of various genotypes is essential for successful future research, treatment and control strategies. In this study, the distribution of HCV genotypes and their association with possible risk factors in a group of HCV infected patients from Kermanshah province of Iran was investigated. HCV viral load test by Real time- PCR method was used for diagnosis of infected cases. The genotypes of cases were revealed using Nested- and Multiplex-PCR and with direct sequencing results were confirmed. Risk factors were also recorded and a multivariate analysis was performed. Among 180 infected people, 138 (76.6\%) with 3a genotype, 35 $(19.4 \%)$ with 1a genotype, $3(1.7 \%)$ with $1 \mathrm{~b}$ genotype and $4(2.2 \%)$ with $3 \mathrm{a}$ and $1 \mathrm{~b}$ were determined. HCV was transmitted by different routes such as intravenous drug abuse (IVDA), tattooing, sexual, blood transfusion and other risk factors. IVDA and sex are the main risk factors in the men and women, respectively. However, $3 \mathrm{a}$ is the predominant genotype in the all groups. This study revealed that $3 \mathrm{a}$ is the most prevalent genotypes in Kermanshah province.
\end{abstract}

Keywords: hepatitis $\mathrm{C}$, Kermanshah, genotype, polymerase chain reaction

\section{Introduction}

Infection to Hepatitis $\mathrm{C}$ virus (HCV) is one of the critical health problems worldwide. $\mathrm{HCV}$ infection is one of the main causes of chronic viral hepatitis, hepatocellular carcinoma and also cirrhosis (Martins et al., 2011). $\mathrm{HCV}$ also is the leading reason for liver transplantation in the United States and it is controversial concepts in organ shortage (Zein, 2000). HCV infection has reached epidemic proportions. Annually, more than one million infected new cases are reported in world (Cooreman \& Schoondermark Van, 1996). Even though, the incidence of new HCV infection is declining, at least in industrialized countries, yet HCV infection with an estimated prevalence of $3 \%$ in the world population is known as heavily burdens public health (Pol et al., 2012).

The HCV genome is an enveloped positive-sense, single-stranded RNA genome, with approximately $10 \mathrm{~kb}$ long. It has marked similarities to those of members of the genera Pestivirus and Flavivirus (Choo et al., 1991). In infected persons, HCV is a reservoir of related genetic variants, referred to as quasispecies (Duarte et al., 1994). The encoding genes for the envelope glycoproteins (E1 and E2), are the most heterogeneous, especially the 81 nucleotides encoding hypervariable region 1 (HVR1) of E2. HVR1 mutation occurs during the natural course of $\mathrm{HCV}$ infection in untreated immunocompetent persons (Higashi et al., 1993). The mutation rate has been estimated to be 0.1 to 0.2 nucleotide substitutions per genome site per year, and several amino acid changes occur over a period of 1 year or more (Kumar et al., 1993).

Up to now, many complete or partial sequences of HCV genome have been reported (Choo et al., 1991; Choo et al., 1989; Inchauspe et al., 1991; Kato et al., 1990; Okamoto et al., 1992) that disclosed marked genetic heterogeneity of the HCV genome (Ohno et al., 1997). HCV strains isolated in different part of the world were classified into 6 genotypes (genotypes 1-6) and numerous subtypes (e.g., subtypes 1a and 1b). Based on the identification of these genomic differences, $\mathrm{HCV}$ has been classified into different strains. Maybe genetic 
heterogeneity of HCV has an important role for some of the differences in disease outcome and that genotypes are the strongest predictor of the virological response to treatment with interferon (IFN) (Zein, 2000; Scott \& Gretch, 2007). Genotypes 1, 2, and 3 are widespread, whereas others are limited to certain geographical areas (Zein, 2000; Simmonds et al., 2005). The prevalence of hepatitis C virus (HCV) in an area is not constant, and depends on the changes in route of infection, which may change over time.

Kermanshah province, located in the west of Iran, has 1.95 million population which $69.7 \%$ reside in urban. While literacy of Kermanshah is $81.7 \%$, this province has more drug abusers compared to neighbour provinces (http://www.amar.org.ir/Default.aspx?tabid=133). Furthermore, Kermanshah shares border with Iraq in the west. The aim of this study was to determine HCV genotype prevalence in Kermanshah Province, Iran. The distribution of $\mathrm{HCV}$ genotypes and their association with possible transmission routes (risk factors) in a group of $\mathrm{HCV}$ infected patients from Kermanshah province where located in western of Iran was investigated, as the data exclusively related to this area is limited.

\section{Patients and Methods}

\subsection{Patients and Ethics}

In a cross-sectional study, a total of 300 people suspect to HCV infection by specialist physicians referred to the Central Medical Laboratory of Kermanshah from 2010 to 2013. Informed consent was signed by all participants. Data were stored in the database with no reference to the subjects' names. The study protocol and the consent forms were reviewed and approved by the Ethic and Research Committee of Kermanshah University of Medical Sciences. EDTA-anticoagulated specimens in less than 2 hours centrifuged and plasma separated.

\subsection{Sampling}

Plasma samples were aliquoted and frozen in $-70^{\circ} \mathrm{C}$ until RNA extraction. Total RNA was extracted by commercial QIAamp Viral RNA Mini kit (QIAGEN).

\subsection{Determination of Viral Load by Quantitative Real-Time PCR}

The viral load was estimated in the peripheral blood specimens using a commercial artus HCV RG RT-PCR kit (QIAGEN) for the detection of HCV RNA using Real-time PCR on ABI Prism 7500 instrument (Applied Biosystems, Foster City, CA). The amplification reaction was performed according to the manufacturer's instructions.

\subsection{HCV Genotyping}

$\mathrm{HCV}$ isolates of viral load positive samples were genotyped using universally accepted method of Ohno et al. (1997). Briefly, based on this method for HCV genotypes manifestation, two rounds of nested PCR was done by one step RT PCR kit (QIAGEN). Core specific primers, Sc2 and Ac2, were applied for the first- turn PCR and two mixtures of primers were used for the second- turn of Multiplex PCR. Primers of mixture A were specific for the detection of 1b, 2a, 2b, and $3 \mathrm{~b} \mathrm{HCV}$ genotypes (234 bp, 139 bp, 337 bp and 176 bp, respectively), while primers of mixture B were used for the detection of 1a, 3a, 4, 5a, and 6a HCV genotypes (208bp, 232bp, 99bp and 336bp, respectively). Meanwhile, the PCR programs of these processes described by Ohno et al. (1997) and primer sequences are shown in Table 1 . The genotype specific band was visualized on a $2.5 \%$ agarose gel by ethidium bromide and UV light (Figure 1). 

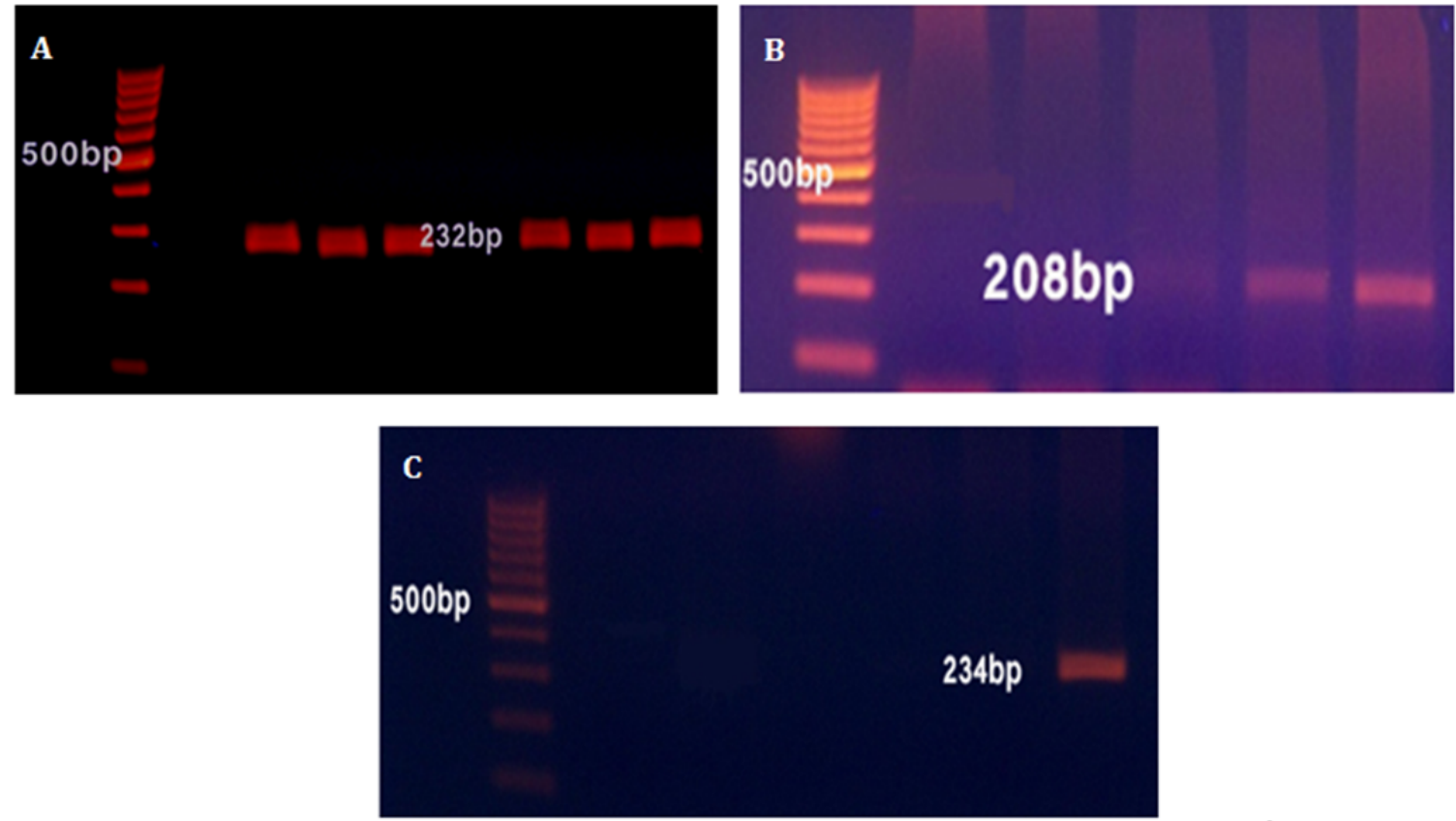

Figure 1. 2.5\% agarose gel electrophoresis of the PCR products of the HCV DNA from different genotypes. DNA marker 500 bp (lane M); A: Genotype 3a; B: Genotype 1a; C: Genotype 1b

Table 1. PCR, sequencing, and genotyping Oligonucleotide primers (modified from Ohno et al. (1997)

\begin{tabular}{lll}
\hline Primer & Sequence $\left(5^{\prime}-3^{\prime}\right)$ & $P C R$ round \\
\hline Sc2 & GGGAGGTCTCGTAGACCGTGCACCATG & $1^{\text {st }}$ round PCR \\
Ac2 & GAG(AC)GG(GT)AT(AG)TACCCCATGAG(AG)TCGGC & $1^{\text {st }}$ round PCR \\
S7 & AGACCGTGCACCATGAGCAC & $2^{\text {nd }}$-round PCR for sequencing \\
A5 & TACGCCGGGGGCA(TG)T(GA)GGGCCCCA & $2^{\text {nd }}$-round PCR for sequencing \\
\hline Mix 1 & & \\
\hline S7 & AGACCGTGCACCATGAGCAC & $2^{\text {nd }}$-round PCR for genotyping \\
S2a & AACACTAACCGTCGCCCACAA & $2^{\text {nd }}-$ round PCR for genotyping \\
G1b & CCTGCCCTCGGGTTGGCTA(AG) & $2^{\text {nd }}-$ round PCR for genotyping \\
G2a & CACGTGGCTGGGATCGCTCC & $2^{\text {nd }}-$ round PCR for genotyping \\
G2b & GGCCCCAATTAGGACGAGAC & $2^{\text {nd }}-$ round PCR for genotyping \\
G3b & CGCTCGGAAGTCTTACGTAC & $2^{\text {nd }}$-round PCR for genotyping \\
\hline Mix2 & & \\
\hline S7 & AGACCGTGCACCATGAGCAC & \\
G1a & GGATAGGCTGACGTCTACCT & $2^{\text {nd }}-$ round PCR for genotyping \\
G3a & GCCCAGGACCGGCCTTCGCT & $2^{\text {nd }}-$ round PCR for genotyping \\
G4 & CCCGGGAACTTAACGTCCAT & $2^{\text {nd }}-$ round PCR for genotyping \\
G5a & GAACCTCGGGGGGAGAGCAA & $2^{\text {nd }}-$ round PCR for genotyping \\
G6a & GGTCATTGGGGCCCCAATGT & $2^{\text {nd }}-$ round PCR for genotyping \\
& $2^{\text {nd }}-$ round PCR for genotyping \\
\hline
\end{tabular}

\subsection{Direct Sequencing}

To test the validity of PCR based genotyping, the nucleotide sequences of HCV core gene from 25 of the 180 specimens were sequenced by ABI 3130 genetic Analyzer instrument (Applied Biosystems, Foster City, Calif.).

\subsection{Statistical Analyses}

Data are presented as percentage (\%) or number of patients. Chi-Square and Fisher's Exact tests were carried out by SPSS statistical package version 14.0 for windows. $P$ values less than 0.05 were considered significant.

\section{Results and Discussion}

From 300 cases referred to Reference Clinical Laboratory 180 case shown viral load positive by Real time PCR 
assay. Among these $180 \mathrm{HCV}$ positive cases, 44 (24.4\%) were female and $136(75.6 \%)$ were male with an age range between 18 to 76 years old. There is a notable statistic; from 180 infected patients, 146 cases $(81.1 \%)$ were connected with suspicious blood; 96 cases were addicted (IVDA), 43 cases had history of tattoo, 5 cases were health center staff, 2 cases had hemophilia and 34 cases (18.9\%) have unknown risk factors (Figure 2) that maybe is related to high risk sexual behavior that didn't declare because of cultural reasons. One important thing in the mentioned data is that 7 cases means $3.9 \%$ of total patients, 5 cases of Health staffs and 2 hemophilia cases, are infected due to fault in Health systems because frequency of $\mathrm{HCV}$ infection in normal population is $0.5-1 \%$ (Merat et al., 2010). This is an unfortunate report that could be a catastrophe for a Health system. Interestingly, $82.36 \%$ of unknown routes group that may referred to high risk sexual behavior cases comprises of women. These cases are not IVDA but almost have addicted spouse.

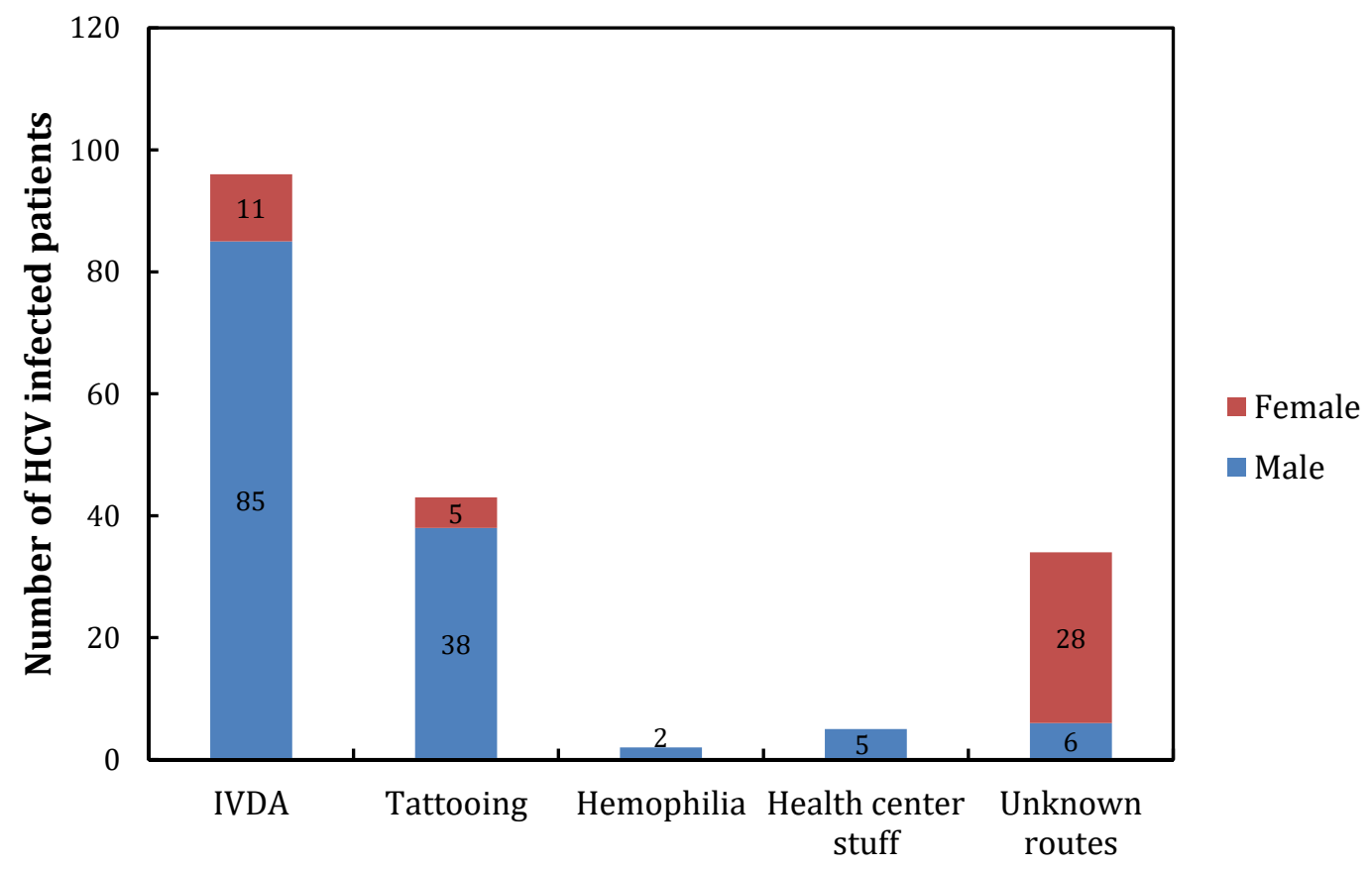

Figure 2. Routes of infection in HCV infected patients

As shown in Figure 3, RT-PCR genotyping results for 180 people infected by HCV showed that 138 people (76.6\%) had 3a genotype, 35 people (19.4\%) had 1a genotype, $3(1.7 \%)$ had $1 \mathrm{~b}$ genotype and finally $4(2.2 \%)$ had $3 \mathrm{a}$ and $1 \mathrm{~b}$ genotype. Genotypes $2 \mathrm{a}, 2 \mathrm{~b}$ and $3 \mathrm{~b}$ were not detected in any samples. Additionally, the results of direct sequencing for 25 cases, randomly selected, strongly confirmed RT-PCR results. 


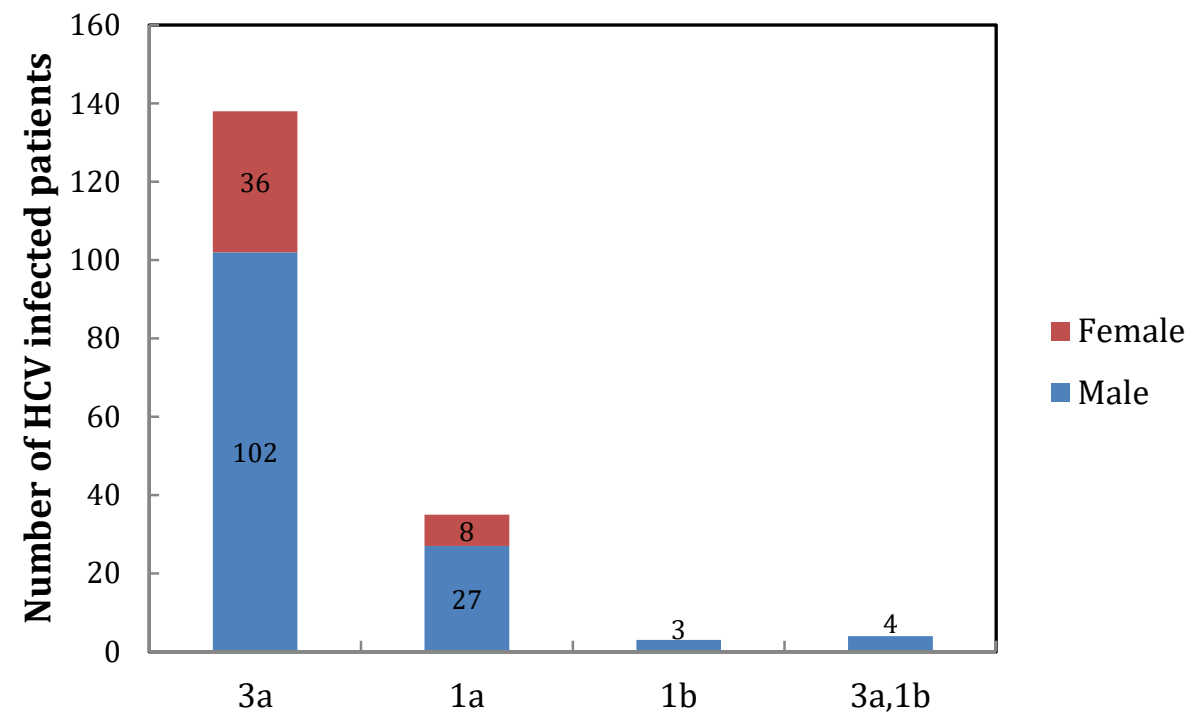

Figure 3. HCV genotype distribution in Kermanshah province

Classification of cases based on risk factors revealed that the predominant HCV genotype is 3a among drug abusers, tattooing and maybe high risk sexual behavior (unknown risk factors) groups (Table 2). These groups comprise of $<45$ years old cases which consist with previous study that demonstrate usually IVDA cases have 3a genotype (Pawlotsky et al., 1995).

Table 2. Hepatitis $\mathrm{C}$ virus genotype subtypes prevalence within transmission route groups

\begin{tabular}{llllll}
\hline \multirow{2}{*}{ Presentation of patients } & \multicolumn{2}{l}{ HCV-genotype } & & \\
\cline { 2 - 5 } & $3 \mathrm{a}(\mathrm{N}=138)$ & $1 \mathrm{a}(\mathrm{N}=35)$ & $1 \mathrm{~b}(\mathrm{~N}=3)$ & $3 \mathrm{a}, 1 \mathrm{~b}(\mathrm{~N}=4)$ & Sig. \\
\hline Male/Female (\%male) & $102 / 36(73.91)$ & $27 / 8(77.14)$ & $3 / 0(100)$ & $4 / 0(100)$ & \\
Transmission routes & & 16 & 0 & 3 & 0.05 \\
IVDA & 77 & 10 & 3 & 1 & $\mathrm{~ns}$ \\
Tattooing & 29 & 2 & 0 & 0 & $\mathrm{~ns}$ \\
Hemophilia & 0 & 1 & 0 & 0 & $\mathrm{~ns}$ \\
Health center stuff & 4 & 6 & 3 & 0 & $\mathrm{~ns}$ \\
Unknown routes & 28 & & &
\end{tabular}

\section{Conclusion}

Different studies indicated that $\mathrm{HCV}$ is the most important etiological factor for transfusion-acquired and sporadic non-A, non-B hepatitis (Ohno et al., 1997; Alter et al., 1989). The variability in HCV genomes has been proven by comparative analysis of $\mathrm{HCV}$ isolates from different geographical regions. The variability in $\mathrm{HCV}$ genotypes leads to different serological reactivity and differences in treatment response (Zein, 2000; Simmonds et al., 2005; Casato et al., 1997; Martinot Peignoux et al., 1995; Manns et al., 2001; McHutchison et al., 2002). Based on sequence variation in both the coding and non-coding regions, several classification systems have been proposed. Ohno et al., classified HCV to $1 \mathrm{a}, 1 \mathrm{~b}, 1 \mathrm{~d}, 2 \mathrm{a}, 2 \mathrm{~b}, 3 \mathrm{a}, 3 \mathrm{~b}, 4,5 \mathrm{a}$, and $6 \mathrm{a}$ isolates, based on the core region PCR with genotype-specific primers, that is widely acceptable (Ohno et al., 1997). Genotypes 1, 2, and 3 of HCV become manifest to have a worldwide distribution; however, their relative prevalence differs from one geographic region to another. $1 \mathrm{~b}$ subtype, in Japan is responsible for about $73 \%$ of HCV infection (Takada et al., 1993). In the United States and Europe, 1a and 1b subtypes are the predominant genotypes (Zein et al., 1996; Dusheiko et al., 1994; Sallie, 1995; McOmish et al., 1994). HCV genotype 3a is more common among the abusers of intravenous drug in the United States and Europe (Pawlotsky et al., 1995). In Middle East genotype 4 of HCV is common (Abdulkarim et al., 1998; Chamberlain et al., 1997). HCV genotype distribution in Tehran, located in the center of Iran, indicated that 3a genotype was the most frequent type (46.6\%), and then type 1 (43.2) is more common (Hajia et al., 2010). Another study in Northeastern of Iran shows 3a (40\%) and 1a (39.2\%) types are most prevalent (Vossughinia et al., 2012). A survey in Southern Iran shows $3 a(26.2 \%)$ and 1 
(11.1\%) genotypes are common (Ziyaeyan et al., 2011). The present study in Western Iran, Kermanshah Province, revealed that $3 \mathrm{a}(76.6 \%)$ and $1 \mathrm{a}(19.4 \%)$ genotypes are prevalent.

In conclusion, these results indicate that type $3 \mathrm{a}$ of $\mathrm{HCV}$ is most prevalent in Kermanshah Province, Iran, which is different from other reports around the world.

\section{Acknowledgment}

This work is sponsored by Kermanshah University of Medical Sciences, Kermanshah, Iran. The sponsor, however, had no direct involvement with this work. This work was performed in partial fulfillment of the requirements for MSc, of Reza Hatami-Moghadam, in Central Medical Laboratory of Kermanshah, Kermanshah University of Medical Sciences, Kermanshah, Iran.

\section{References}

Abdulkarim, A. S., Zein, N. N., Germer, J. J., Kolbert, C. P., Kabbani, L., Krajnik, K. L., ... Persing, D. H. (1998). Hepatitis $\mathrm{C}$ virus genotypes and hepatitis $\mathrm{G}$ virus in hemodialysis patients from Syria: identification of two novel hepatitis $C$ virus subtypes. The American journal of tropical medicine and hygiene, 59(4), 571-576.

Alter, H. J., Purcell, R. H., Shih, J. W., Melpolder, J. C., Houghton, M., Choo, Q. L., \& Kuo, G. (1989). Detection of Antibody to Hepatitis C Virus in Prospectively Followed Transfusion Recipients with Acute and Chronic Non-A, Non-B Hepatitis. New England Journal of Medicine, 321(22), 1494-1500. http://dx.doi.org/10.1056/nejm198911303212202

Casato, M., Agnello, V., Pucillo, L. P., Knight, G. B., Leoni, M., Del Vecchio, S., ... Bonomo, L. (1997). Predictors of long-term response to high-dose interferon therapy in type II cryoglobulinemia associated with hepatitis C virus infection. Blood, 90(10), 3865-3873.

Chamberlain, R. W., Simmonds, P., Adams, N., Elliott, R. M., \& Saeed, A. A. (1997). Complete nucleotide sequence of a type 4 hepatitis $\mathrm{C}$ virus variant, the predominant genotype in the Middle East. Journal of General Virology, 78(6), 1341-1347. http://dx.doi.org/10.1099/0022-1317-78-6-1341

Choo, Q. L., Richman, K. H., Han, J. H., Berger, K., Lee, C., Dong, C., ... Barr, P. J. (1991). Genetic organization and diversity of the hepatitis C virus. Proceedings of the National Academy of Sciences, 88(6), 2451-2455. http://dx.doi.org/10.1073/pnas.88.6.2451

Choo, Q., Kuo, G., Weiner, A., Overby, L., Bradley, D., \& Houghton, M. (1989). Isolation of a cDNA clone derived from a blood-borne non-A, non-B viral hepatitis genome. Science, 244(4902), 359-362. http://dx.doi.org/10.1126/science.2523562

Cooreman, M. P., \& Schoondermark Van De Ven, E. M. E. (1996). Hepatitis C Virus: Biological and Clinical Consequences of Genetic Heterogeneity. Scandinavian Journal of Gastroenterology, 31(s218), 106-115. http://dx.doi.org/10.3109/00365529609094740

Duarte, E. A., Novella, I. S., Weaver, S. C., Domingo, E., Wain Hobson, S., Clarke, D. K., ... Holland, J. J. (1994). RNA virus quasispecies: significance for viral disease and epidemiology. Infectious agents and disease, 3(4), 201-214.

Dusheiko, G., Schmilovitz Weiss, H., Brown, D., McOmish, F., Yap, P. L., Sherlock, S., ... Simmonds, P. (1994). Hepatitis $\mathrm{C}$ virus genotypes: An investigation of type-specific differences in geographic origin and disease. Hepatology, 19(1), 13-18. http://dx.doi.org/10.1002/hep.1840190104

Hajia, M., Amirzargar, A. A., Khedmat, H., Shahrokhi, N., Farzanehkhah, M., Ghorishi, S. M., ... Sarafnejad, A. (2010). Genotyping pattern among Iranian HCV positive patients. Iranian journal of public health, 39(2), 39-44.

Higashi, Y., Kakumu, S., Yoshioka, K., Wakita, T., Mizokami, M., Ohba, K., ... Nagai, Y. (1993). Dynamics of Genome Change in the E2/NS1 Region of Hepatitis C Virus in Vivo. Virology, 197(2), 659-668. http://dx.doi.org/10.1006/viro.1993.1641

Inchauspe, G., Zebedee, S., Lee, D. H., Sugitani, M., Nasoff, M., \& Prince, A. M. (1991). Genomic structure of the human prototype strain $\mathrm{H}$ of hepatitis $\mathrm{C}$ virus: comparison with American and Japanese isolates. Proceedings of the National Academy of Sciences, 88(22), 10292-10296. http://dx.doi.org/10.1073/pnas.88.22.10292

Kato, N., Hijikata, M., Ootsuyama, Y., Nakagawa, M., Ohkoshi, S., Sugimura, T., \& Shimotohno, K. (1990). Molecular cloning of the human hepatitis $\mathrm{C}$ virus genome from Japanese patients with non-A, non-B hepatitis. Proceedings of the National Academy of Sciences, 87(24), 9524-9528. 
http://dx.doi.org/10.1073/pnas.87.24.9524

Kumar, U., Brown, J., Monjardino, J., \& Thomas, H. C. (1993). Sequence Variation in the Large Envelope Glycoprotein (E2jNSl) of Hepatitis C Virus during Chronic Infection. Journal of Infectious Diseases, 167(3), 726-730. http://dx.doi.org/10.1093/infdis/167.3.726

Manns, M. P., McHutchison, J. G., Gordon, S. C., Rustgi, V. K., Shiffman, M., Reindollar, R., ... Albrecht, J. K. (2001). Peginterferon alfa-2b plus ribavirin compared with interferon alfa-2b plus ribavirin for initial treatment of chronic hepatitis $\mathrm{C}$ : a randomised trial. The Lancet, 358(9286), 958-965. http://dx.doi.org/10.1016/s0140-6736(01)06102-5

Martinot Peignoux, M., Marcellin, P., Pouteau, M., Castelnau, C., Boyer, N., Poliquin, M., ... Erlinger, S. (1995). Pretreatment serum hepatitis $\mathrm{C}$ virus RNA levels and hepatitis $\mathrm{C}$ virus genotype are the main and independent prognostic factors of sustained response to interferon alfa therapy in chronic hepatitis $\mathrm{C}$. Hepatology, 22(4), 1050-1056. http://dx.doi.org/10.1002/hep.1840220406

Martins, T., Narciso Schiavon, J. L., \& Schiavon, L. L. (2011). Epidemiology of hepatitis C virus infection. Revista Da Associação Médica Brasileira, 57(1), 105-110. http://dx.doi.org/10.1016/s0104-4230(11)70024-0

McHutchison, J. G., Manns, M., Patel, K., Poynard, T., Lindsay, K. L., Trepo, C., ... Albrecht, J. K. (2002). Adherence to combination therapy enhances sustained response in genotype-1-infected patients with chronic hepatitis C. Gastroenterology, 123(4), 1061-1069. http://dx.doi.org/10.1053/gast.2002.35950

McOmish, F., Yap, P. L., Dow, B. C., Follett, E. A., Seed, C., Keller, A. J., ... Naukkarinen, R. (1994). Geographical distribution of hepatitis $\mathrm{C}$ virus genotypes in blood donors: an international collaborative survey. Journal of Clinical Microbiology, 32(4), 884-892.

Merat, S., Rezvan, H., Nouraie, M., Jafari, E., Abolghasemi, H., Radmard, A. R., ... Esmaili, S. (2010). Seroprevalence of hepatitis $\mathrm{C}$ virus: the first population-based study from Iran. International Journal of Infectious Diseases, 14, e113-e116. http://dx.doi.org/10.1016/j.ijid.2009.11.032

Ohno, O., Mizokami, M., Wu, R. R., Saleh, M. G., Ohba, K. I., Orito, E., ... Lau, J. Y. (1997). New hepatitis C virus $(\mathrm{HCV})$ genotyping system that allows for identification of $\mathrm{HCV}$ genotypes 1a, 1b, 2a, 2b, 3a, 3b, 4, 5a, and 6a. Journal of clinical microbiology, 35(1), 201-207.

Okamoto, H., Kurai, K., Okada, S. I., Yamamoto, K., Lizuka, H., Tanaka, T., ... Mishiro, S. (1992). Full-length sequence of a hepatitis $\mathrm{C}$ virus genome having poor homology to reported isolates: Comparative study of four distinct genotypes. Virology, 188(1), 331-341. http://dx.doi.org/10.1016/0042-6822(92)90762-e

Pawlotsky, J. M., Tsakiris, L., Roudot Thoraval, F., Pellet, C., Stuyver, L., Duval, J., \& Dhumeaux, D. (1995). Relationship between Hepatitis C Virus Genotypes and Sources of Infection in Patients with Chronic Hepatitis C. Journal of Infectious Diseases, 171(6), 1607-1610. http://dx.doi.org/10.1093/infdis/171.6.1607

Pol, S., Vallet Pichard, A., Corouge, M., \& Mallet, V. O. (2012). Hepatitis C: Epidemiology, Diagnosis, Natural History and Therapy. Contributions to Nephrology, 176, 1-9. http://dx.doi.org/10.1159/000332374

Sallie, R. (1995). Hepatitis C virus type 1b (II) infection in France and Italy Nousbaum JB, Pol S, Nalpas B, Landais P, Berthelot P, Brechot C, and the Collaborative Study Group. Hepatology, 22(2), 671-674. http://dx.doi.org/10.1016/0270-9139(95)90597-9

Scott, J. D., \& Gretch, D. R. (2007). Molecular Diagnostics of Hepatitis C Virus Infection. JAMA, 297(7), 724. http://dx.doi.org/10.1001/jama.297.7.724

Simmonds, P., Bukh, J., Combet, C., Deléage, G., Enomoto, N., Feinstone, S., .. Widell, A. (2005). Consensus proposals for a unified system of nomenclature of hepatitis C virus genotypes. Hepatology, 42(4), 962-973. http://dx.doi.org/10.1002/hep.20819

Takada, N., Takase, S., Takada, A., \& Date, T. (1993). Differences in the hepatitis C virus genotypes in different countries. Journal of Hepatology, 17(3), 277-283. http://dx.doi.org/10.1016/s0168-8278(05)80205-3

Vossughinia, H., Goshayeshi, L. A., Bayegi, H. R., Sima, H., Kazemi, A., Erfani, S., ... Jamehdar, S. A. (2012). Prevalence of hepatitis C virus genotypes in Mashhad, Northeast Iran. Iranian journal of public health, 41(9), 56-61.

Zein, N. N. (2000). Clinical Significance of Hepatitis C Virus Genotypes. Clinical Microbiology Reviews, 13(2), 223-235. http://dx.doi.org/10.1128/cmr.13.2.223-235.2000 
Zein, N. N., Rakela, J., Krawitt, E. L., Reddy, K. R., Tominaga, T., \& Persing, D. H. (1996). Hepatitis C virus genotypes in the United States: epidemiology, pathogenicity, and response to interferon therapy. Annals of internal medicine, 125(8), 634-639.

Ziyaeyan, M., Alborzi, A., Jamalidoust, M., Badiee, P., \& Moeini, M. (2011). Prevalence of hepatitis C virus genotypes in chronic infected patients, southern Iran. Jundishapur Journal of Microbiology, 4(3), 141-146.

\section{Copyrights}

Copyright for this article is retained by the author(s), with first publication rights granted to the journal.

This is an open-access article distributed under the terms and conditions of the Creative Commons Attribution license (http://creativecommons.org/licenses/by/3.0/). 